\title{
GST gene family polymorphism and the risk of colorectal cancer in patients with type 2 diabetes
}

\section{Polimorfizm genów rodziny GST a ryzyko wystapienia raka jelita grubego u pacjentów z cukrzycą typu 2} \author{
Anna Cedro ${ }^{1}$, Stanisław Głuszek ${ }^{1}$, Iwona Wawrzycka ${ }^{1}$, Ewa Orlewska ${ }^{1}$ \\ ${ }^{1}$ Collegium Medicum, Jan Kochanowski University, Kielce, Poland \\ Head of the Collegium: Prof. Marianna Janion MD, PhD \\ ${ }^{2}$ Department of Pathomorphology, Central Clinical Hospital of MSWiA, Warsaw, Poland \\ Head of the Department: Prof. Anna Nasierowska-Guttmejer MD, PhD \\ ${ }^{3}$ Department of Internal Medicine, Tytus Chałubiński Hospital, Zakopane, Poland \\ Head of the Department: Łukasz Błoński MD \\ ${ }^{4}$ Institute of Biology, Jan Kochanowski University, Kielce, Poland \\ Head of the Institute: Joanna Czerwik-Marcinkowska PhD, Prof. JKU
}

Justyna E. Klusek ${ }^{1}$, Anna Nasierowska-Guttmejer², Katarzyna Orlewska³, Łukasz Madej ${ }^{1}$, Jolanta Klusek ${ }^{4}$,

Key words: colorectal cancer, glutathione S-transferase, GST genes polymorphism, type 2 diabetes.

Słowa kluczowe: rak jelita grubego, transferaza-S glutationu, polimorfizm genów GST, cukrzyca typu 2.

\begin{abstract}
Aim of the research: To investigate whether the polymorphisms of GSTP1, GSTT1 and GSTM1 genes are associated with colorectal cancer in a sample of Polish patients with and without type 2 diabetes.

Material and methods: Over 200 patients aged $>40$ years were recruited and divided into 4 age-matched groups: patients with diagnosed type 2 diabetes, patients with diagnosed type 2 diabetes and colorectal cancer, patients with colorectal cancer and without type 2 diabetes and patients without type 2 diabetes and without colorectal cancer. DNA for genetic testing was isolated from blood samples. The GST gene polymorphism was examined using qPCR method, with TaqMan probes. It included GSTP1 SNP Ile105Val (rs1695) polymorphism, and deletion of copies of GSTT1 and GSTM1 genes (genotypes GSTT1 null/null and GSTM1 null/null).

Results: The analysis of the frequency of GST gene polymorphisms in the group of patients with type 2 diabetes and colorectal cancer compared to patients with type 2 diabetes showed no statistically significant differences. There were also no statistically significant differences in the distribution of GST gene polymorphisms between patients with diabetes or/and colorectal cancer and population without these diseases.

Conclusions: Extending the analysis to further genetic and environmental factors and taking into account their mutual interactions is needed to search for the relationship between type 2 diabetes and an increased risk of colorectal cancer.
\end{abstract}

\section{Streszczenie}

Cel pracy: Określenie, czy polimorfizmy genów GSTP1, GSTT1 i GSTM1 są związane z rakiem jelita grubego w populacji polskich pacjentów z cukrzycą typu 2 i bez cukrzycy.

Materiał i metody: Ponad 200 pacjentów powyżej 40. roku życia zostało zrekrutowanych do badania i podzielonych na 4 grupy dopasowane wiekowo: pacjenci ze zdiagnozowaną cukrzycą typu 2, pacjenci ze zdiagnozowanymi cukrzycą typu 2 i rakiem jelita grubego, pacjenci z rakiem jelita grubego, bez cukrzycy typu 2, pacjenci bez raka jelita grubego i bez cukrzycy. DNA do badań genetycznych izolowano z próbek krwi. Polimorfizm genów GST badano z użyciem metody qPCR i sond typu Taqman. Badanie obejmowało polimorfizm typu SNP Ile105Val (rs 1695) oraz delecje kopii genów GSTT1 i GSTM1 (genotypy GSTT1 null/null oraz GSTM1 null/null).

Wyniki: Analiza częstości występowania polimorfizmów genów GST u pacjentów z cukrzycą typu 2 i rakiem jelita grubego w porównaniu z pacjentami z cukrzycą typu 2 bez raka nie wykazała statystycznie istotnych różnic. Nie stwierdzono również istotnych różnic w dystrybucji polimorfizmów genów GST pomiędzy osobami z cukrzycąi/lub chorymi na raka jelita grubego a grupą bez tych schorzeń.

Wnioski: W celu określenia związku pomiędzy cukrzycą typu 2 a zwiększonym ryzykiem wystąpienia raka jelita grubego konieczne jest rozszerzenie analizy o kolejne czynniki genetyczne i środowiskowe z uwzględnieniem ich wzajemnych interakcji. 


\section{Introduction}

Type 2 diabetes (T2D) and colorectal cancer (CRC) are two civilization diseases with very high morbidity and mortality all over the world. A number of epidemiological studies have shown that individuals with T2D have a higher risk of developing CRC compared with their non-diabetic counterparts: the risk of CRC was estimated to be $27 \%$ higher in patients with T2D than in non-diabetic controls [1]. Several mechanisms have been proposed to partially explain the higher prevalence of CRC in people with T2D: hyperglycemia, hyperinsulinemia, insulin resistance, local inflammation/oxidative stress, extracellular matrix alterations, altered microbiota, and obesity [1]. Not much is known about the role of genetic predisposition in the association between T2D and CRC. Research from recent years investigates potential genetic risk factors for T2D and CRC concerning, among others, genes related to ion transport, regulation of gene expression, carbohydrate and lipid metabolism and detoxification processes [2, 3]. According to various publications, genes encoding glutathione S-transferases (GST) are of significant importance [4-6]. GST are members of the antioxidant enzyme group which play an important role in detoxification by catalyzing the conjugation of many hydrophobic and electrophilic compounds with reduced glutathione. They are responsible for neutralizing xenobiotics, environmental pollutants, carcinogens and reactive oxygen species [7]. GST genes are highly polymorphic in the Caucasian population. The GSTP1 gene polymorphism is most often SNP (Single Nucleotide Polymorphism) within exon 5 Ile105Val. The exchange of isoleucine and valine in the amino acid chain results in a decreased enzymatic activity of the protein. The average frequency of this gene variant in Europe is about 50\% [8]. Inherited homozygous deletion of GSTT1 or GSTM1 gene leads to a complete absence of enzymatic activity, which occurs with an average frequency of $20 \%$ and $40 \%$ in the Caucasian population, respectively [9]. According to research, the polymorphism of GST genes may influence the risk of developing T2D, as well as its course, complications and treatment effectiveness $[9,10]$. Similar observations were made for CDC, where the GST genotype may be a factor modifying the risk of disease development and progression [7, 11, 12].

\section{Aim of the research}

The aim of the study was to investigate whether the polymorphisms of GSTP1, GSTT1 and GSTM1 genes are associated with CRC in a sample of Polish patients with and without T2D.

\section{Material and methods}

\section{Study population}

Two hundred and twenty patients aged $>40$ years were recruited in Kielce, Poland from the Provin- cial Hospital, the Holy Cross Cancer Center and the Witamed diabetic outpatient center. Patients were divided into 4 age-matched groups: patients with diagnosed T2D (group 1), patients with diagnosed T2D and CRC (group 2), patients with CRC and without T2D (group 3) and patients without T2D and without CRC (group 4). T2D diagnosis was determined by a diabetologist according to the revised criteria of the American Association of Diabetology [13]. CRC was confirmed based on a pathomorphological diagnosis of specimens collected during colonoscopy or surgery. Patients with predisposition to CRC, e.g. FAP (Familial Adenoma Polyposis Coli), Lynch Syndrome, history of endocrine disorders, alcoholism, diabetes secondary to chronic pancreatitis, Cushing's disease with treatment that can induce hyperglycemia, T1D. Pregnant or lactating women were excluded from the study. The control group comprised volunteers without T2D, according to the medical history and laboratory tests and without CRC as confirmed by an endoscopic and/ or histopathological examination. All patients signed written consent forms prior to participation in the study. The study was approved on June 3, 2013 by the local Bioethics Commission (No. 5/2013), next - with new aspects of the study - on May 28, 2019 by the local Bioethics Commission (No. 27/2019) on the basis of an application with an exact description of the procedure. All procedures were conducted according to the principles of the Helsinki Declaration.

\section{Genotyping}

Peripheral blood was collected to EDTA probes and frozen at $-40^{\circ} \mathrm{C}$. Genomic DNA was the material for genetic testing, isolated from blood samples using the Genomic Micro AX Blood Gravity kit from AA Biotechnology. The purity and concentration of the isolated DNA were evaluated spectrophotometrically at $260 \mathrm{~nm}$ and $280 \mathrm{~nm}$ (Nanodrop 2000 Thermo Fisher Scientific). Analysis of the SNP (rs1695) polymorphism of the GSTP1 gene was conducted using the TaqMan qPCR method - endpoint genotyping (Assay ID C_3237198_20). The deletion of copies of genes GSTT1 (Assay ID Hs00010004_cn) and GSTM1 (Assay ID Hs02575461_cn) was analyzed using the qPCR relative quantification method with the TERT control gene. In all cases, the Light Cycler 96 instrument and TaqMan primer/probe kit (produced by Life Technology) were used. PCR amplification using 10ng of genomic DNA was performed with an initial step of $95^{\circ} \mathrm{C}$ for $10 \mathrm{~min}$ followed by 50 cycles of $95^{\circ} \mathrm{C}$ for $15 \mathrm{~s}$ and $60^{\circ} \mathrm{C}$ for $90 \mathrm{~s}$.

\section{Statistical analysis}

Continuous data were described by means, standard deviations, medians and interquartile ranges, whereas categorical data were summarized by frequencies and percentages. Group comparisons were 
Table 1. Demographic characteristics (age and sex) of the studied population divided by diseases

\begin{tabular}{|lcccc|}
\hline Parameter & A & B & C & D \\
\cline { 2 - 5 } & $\begin{array}{c}\text { CRC-, T2D- } \\
(n=55)\end{array}$ & $\begin{array}{c}\text { CRC-, T2D+ } \\
(n=55)\end{array}$ & $\begin{array}{c}\text { CRC+, T2D- } \\
(n=55)\end{array}$ & $\begin{array}{c}\text { CRC+, T2D+ } \\
(n=55)\end{array}$ \\
\hline Age: & $65.7(7.0)$ & $66.0(6.5)$ & $65.9(6.6)$ & $66.0(6.5)$ \\
\hline Mean (SD) & 65.0 & 66.0 & 66.0 & 66.0 \\
\hline Median & $(62.0,70.0)$ & $(62.0,70.0)$ & $(62.0,70.0)$ & $(62.0,70.0)$ \\
$\left(\mathrm{Q}_{1}, \mathrm{Q}_{3}\right)$ & $47.0-81.0$ & $51.0-81.0$ & $51.0-81.0$ & $52.0-80.0$ \\
\hline Range & & & & $21(38.2 \%)$ \\
Sex $:$ & $31(56.4 \%)$ & $28(50.9 \%)$ & $32(58.2 \%)$ & $34(61.8 \%)$ \\
\hline Female & $24(43.6 \%)$ & $27(49.1 \%)$ & & \\
\hline Male & & & & \\
\hline
\end{tabular}


vs. $C p=0.3391$, group $B$ vs. $D p=0.1793$, group $C$ vs. $D p=0.6971$.

Table 2. GST gene polymorphism in T2D patients with CRC vs. T2D patients without CRC

\begin{tabular}{|c|c|c|c|c|c|}
\hline Variable & $\begin{array}{c}\text { T2D+, CRC+ } \\
(n=55)\end{array}$ & $\begin{array}{c}\text { T2D+, CRC- } \\
(n=55)\end{array}$ & $\mathrm{OR}^{1}$ & $95 \% \mathrm{Cl}$ & $P$-value \\
\hline \multicolumn{6}{|l|}{ GSTP1: } \\
\hline Ile/lle & $24(43.6 \%)$ & $26(47.3 \%)$ & & & \\
\hline Ile/Val & $28(50.9 \%)$ & $20(36.4 \%)$ & & & \\
\hline Val/Val & $3(5.5 \%)$ & $9(16.4 \%)$ & & & \\
\hline \multicolumn{6}{|l|}{ GSTP1: } \\
\hline Ile/lle or Ile/Val & $52(94.5 \%)$ & $46(83.6 \%)$ & Ref. level & & \\
\hline Val/Val & $3(5.5 \%)$ & $9(16.4 \%)$ & 0.29 & $0.08-1.16$ & 0.0796 \\
\hline \multicolumn{6}{|l|}{ GSTT1: } \\
\hline Wild type & $45(81.8 \%)$ & $43(78.2 \%)$ & Ref. level & & \\
\hline Null/null & $10(18.2 \%)$ & $12(21.8 \%)$ & 0.80 & $0.31-2.03$ & 0.6339 \\
\hline \multicolumn{6}{|l|}{ GSTM1: } \\
\hline Wild type & $27(49.1 \%)$ & $28(50.9 \%)$ & Ref. level & & \\
\hline Null/null & $28(50.9 \%)$ & $27(49.1 \%)$ & 1.08 & $0.51-2.27$ & 0.8488 \\
\hline \multicolumn{6}{|l|}{ Combined: } \\
\hline $\mathrm{P} 1=$ wild, $M 1=$ wild, $\mathrm{T} 1=$ wild & $10(18.2 \%)$ & $6(10.9 \%)$ & & & \\
\hline P1 = wild, M1 = wild, T1 = null/null & $1(1.8 \%)$ & $6(10.9 \%)$ & & & \\
\hline P1 = wild, M1 = null/null, T1 = wild & $10(18.2 \%)$ & $12(21.8 \%)$ & & & \\
\hline $\mathrm{P} 1=$ wild, $\mathrm{M} 1=$ null $/$ null, $\mathrm{T} 1=$ null $/$ null & $3(5.5 \%)$ & $2(3.6 \%)$ & & & \\
\hline $\mathrm{P} 1=\mathrm{SNP} *, \mathrm{M} 1=$ wild, $\mathrm{T} 1=$ wild & $12(21.8 \%)$ & $14(25.5 \%)$ & & & \\
\hline $\mathrm{P} 1=\mathrm{SNP} \mathrm{P}^{\star}, \mathrm{M} 1=$ wild, $\mathrm{T} 1=$ null$/$ null & $4(7.3 \%)$ & $2(3.6 \%)$ & & & \\
\hline $\mathrm{P} 1=\mathrm{SNP}{ }^{\star}, \mathrm{M} 1=$ null$/$ null, $\mathrm{T} 1=$ wild & $13(23.6 \%)$ & $11(20.0 \%)$ & & & \\
\hline $\mathrm{P} 1=\mathrm{SNP} \mathrm{P}^{*}, \mathrm{M} 1=\mathrm{null} / \mathrm{null}, \mathrm{T} 1=$ null $/$ null & $2(3.6 \%)$ & $2(3.6 \%)$ & & & \\
\hline \multicolumn{6}{|l|}{ GST polymorphism presence: } \\
\hline No & $10(18.2 \%)$ & $6(10.9 \%)$ & & & \\
\hline Yes & $45(81.8 \%)$ & 49 (89.1\%) & & & \\
\hline
\end{tabular}

${ }^{1}$ Unadjusted. CRC - colorectal cancer, T2D - type 2 diabetes, GST - glutathione S-transferase. SNP* - GSTP1 polymorphism Ile105Val, heterozygous (Ile/Val) or homozygous Val/Val genotype. 
Table 3. GST gene polymorphism in T2D patients without CRC in comparison to the control group

\begin{tabular}{|c|c|c|c|c|c|}
\hline Variable & $\begin{array}{c}\text { T2D+, CRC- } \\
(n=55)\end{array}$ & $\begin{array}{l}\text { T2D-, CRC- } \\
(n=55)\end{array}$ & $\mathrm{OR}^{1}$ & $95 \% \mathrm{Cl}$ & $P$-value \\
\hline \multicolumn{6}{|l|}{ GSTP1: } \\
\hline Ile/lle & $26(47.3 \%)$ & $26(47.3 \%)$ & & & \\
\hline Ile/Val & $20(36.4 \%)$ & $24(43.6 \%)$ & & & \\
\hline Val/Val & $9(16.4 \%)$ & $5(9.1 \%)$ & & & \\
\hline \multicolumn{6}{|l|}{ GSTP1: } \\
\hline Ile/lle or Ile/Val & $46(83.6 \%)$ & $50(90.9 \%)$ & Ref. level & & \\
\hline Val/Val & $9(16.4 \%)$ & $5(9.1 \%)$ & 1.96 & $0.61-6.27$ & 0.2585 \\
\hline \multicolumn{6}{|l|}{ GSTT1: } \\
\hline Wild type & $43(78.2 \%)$ & $46(83.6 \%)$ & Ref. level & & \\
\hline Null/null & $12(21.8 \%)$ & $9(16.4 \%)$ & 1.43 & $0.55-3.72$ & 0.4680 \\
\hline \multicolumn{6}{|l|}{ GSTM1: } \\
\hline Wild type & $28(50.9 \%)$ & $32(58.2 \%)$ & Ref. level & & \\
\hline Null/null & $27(49.1 \%)$ & $23(41.8 \%)$ & 1.34 & $0.63-2.85$ & 0.4441 \\
\hline \multicolumn{6}{|l|}{ Combined: } \\
\hline $\mathrm{P} 1=$ wild, $M 1=$ wild, $\mathrm{T} 1=$ wild & $6(10.9 \%)$ & $14(25.5 \%)$ & & & \\
\hline $\mathrm{P} 1=$ wild, $M 1=$ wild, $\mathrm{T} 1=$ null $/$ null & $6(10.9 \%)$ & $3(5.5 \%)$ & & & \\
\hline $\mathrm{P} 1=$ wild, $M 1=$ null $/$ null, $T 1=$ wild & $12(21.8 \%)$ & $8(14.5 \%)$ & & & \\
\hline $\mathrm{P} 1=$ wild, $M 1=$ null $/$ null, $T 1=$ null $/$ null & $2(3.6 \%)$ & $1(1.8 \%)$ & & & \\
\hline $\mathrm{P} 1=\mathrm{SNP}{ }^{*}, \mathrm{M} 1=$ wild, $\mathrm{T} 1=$ wild & $14(25.5 \%)$ & $13(23.6 \%)$ & & & \\
\hline $\mathrm{P} 1=\mathrm{SNP} *, \mathrm{M} 1=$ wild, $\mathrm{T} 1=$ null $/$ null & $2(3.6 \%)$ & $2(3.6 \%)$ & & & \\
\hline $\mathrm{P} 1=\mathrm{SNP}^{*}, \mathrm{M} 1=$ null$/$ null, $\mathrm{T} 1=$ wild & $11(20.0 \%)$ & $11(20.0 \%)$ & & & \\
\hline $\mathrm{P} 1=\mathrm{SNP}^{\star}, \mathrm{M} 1=$ null $/$ null, $\mathrm{T} 1=$ null $/$ null & $2(3.6 \%)$ & $3(5.5 \%)$ & & & \\
\hline \multicolumn{6}{|l|}{ GST polymorphism presence: } \\
\hline No & $6(10.9 \%)$ & $14(25.5 \%)$ & & & \\
\hline Yes & 49 (89.1\%) & $41(74.5 \%)$ & & & \\
\hline
\end{tabular}

${ }^{1}$ Unadjusted, CRC - colorectal cancer, T2D - type 2 diabetes, GST - glutathione S-transferase. SNP* - GSTP1 polymorphism Ile105Val, heterozygous (lle/Val) or homozygous Val/Val genotype.

performed using $\chi^{2}$ or Fisher exact test for categorical variables or Mann-Whitney test for continuous, nonnormally distributed variables (normality of distribution was checked with the Shapiro-Wilk test). Odds ratios (OR) with 95\% confidence intervals (95\% CI) were calculated in logistic regression models. A twotailed $p$-value $<0.05$ was considered statistically significant. All statistical analyses were performed using the R software package version 3.6.2.

\section{Results}

The general characteristics of the studied population divided into four groups are presented in Table 1 . The mean age of patients in each group is approximately 66 years, which is above the mean age of the CRC and T2D onset in the Caucasian population [14,
15]. There was no significant difference in sex distribution between the analyzed groups.

The analysis of the frequency of GST gene polymorphisms in the group of patients with T2D and CRC compared to patients with T2D showed no statistically significant differences (Table 2). Therefore, it may be assumed that the polymorphism of the GSTM1, GSTT1 or GSTP1 genes is not a factor associated with the increased risk of CRC in patients with T2D. Tables 3-5 present the frequency of GST gene polymorphisms in the 3 case groups (patients with T2D, patients with CRC and patients with T2D and $\mathrm{CRC}$ ) in comparison to the control group (patients without T2D and CRC). None of the case groups differed statistically significantly from the control group in terms of the frequency of particular genotypes analyzed separately or in combination. 
Table 4. GST gene polymorphism in CRC patients without T2D in comparison to the control group

\begin{tabular}{|c|c|c|c|c|c|}
\hline Variable & $\begin{array}{c}\text { T2D-, CRC+ } \\
(n=55)\end{array}$ & $\begin{array}{l}\text { T2D-, CRC- } \\
(n=55)\end{array}$ & $\mathrm{OR}^{1}$ & $95 \% \mathrm{Cl}$ & $P$-value \\
\hline \multicolumn{6}{|l|}{ GSTP1: } \\
\hline Ile/lle & $25(45.5 \%)$ & $26(47.3 \%)$ & & & \\
\hline Ile/Val & $24(43.6 \%)$ & $24(43.6 \%)$ & & & \\
\hline Val/Val & $6(10.9 \%)$ & $5(9.1 \%)$ & & & \\
\hline \multicolumn{6}{|l|}{ GSTP1: } \\
\hline Ile/lle or Ile/Val & 49 (89.1\%) & $50(90.9 \%)$ & Ref. level & & \\
\hline $\mathrm{Val} / \mathrm{Val}$ & $6(10.9 \%)$ & $5(9.1 \%)$ & 1.22 & $0.35-4.28$ & 0.7509 \\
\hline \multicolumn{6}{|l|}{ GSTT1: } \\
\hline Wild type & $49(89.1 \%)$ & $46(83.6 \%)$ & Ref. level & & \\
\hline Null/null & $6(10.9 \%)$ & $9(16.4 \%)$ & 0.63 & $0.21-1.90$ & 0.4074 \\
\hline \multicolumn{6}{|l|}{ GSTM1: } \\
\hline Wild type & $31(56.4 \%)$ & $32(58.2 \%)$ & Ref. level & & \\
\hline Null/null & $24(43.6 \%)$ & $23(41.8 \%)$ & 1.08 & $0.51-2.29$ & 0.8472 \\
\hline \multicolumn{6}{|l|}{ Combined: } \\
\hline P1 = wild, M1 = wild, T1 = wild & $17(30.9 \%)$ & $14(25.5 \%)$ & & & \\
\hline P1 = wild, M1 = wild, T1 = null/null & $0(0.0 \%)$ & $3(5.5 \%)$ & & & \\
\hline P1 = wild, M1 = null/null, T1 = wild & $8(14.5 \%)$ & $8(14.5 \%)$ & & & \\
\hline $\mathrm{P} 1=$ wild, $M 1=$ null $/$ null, $T 1=$ null $/$ null & $0(0.0 \%)$ & $1(1.8 \%)$ & & & \\
\hline $\mathrm{P} 1=\mathrm{SNP} \mathrm{N}^{\star}, \mathrm{M} 1=$ wild, $\mathrm{T} 1=$ wild & $13(23.6 \%)$ & $13(23.6 \%)$ & & & \\
\hline $\mathrm{P} 1=\mathrm{SNP}{ }^{*}, \mathrm{M} 1=$ wild, $\mathrm{T} 1=$ null $/$ null & $1(1.8 \%)$ & $2(3.6 \%)$ & & & \\
\hline $\mathrm{P} 1=\mathrm{SNP} P^{*}, \mathrm{M} 1=$ null$/$ null, $\mathrm{T} 1=$ wild & $11(20.0 \%)$ & $11(20.0 \%)$ & & & \\
\hline $\mathrm{P} 1=\mathrm{SNP} \mathrm{P}^{*}, \mathrm{M} 1=$ null $/$ null, $\mathrm{T} 1=\mathrm{null} / \mathrm{null}$ & $5(9.1 \%)$ & $3(5.5 \%)$ & & & \\
\hline \multicolumn{6}{|l|}{ GST polymorphism presence: } \\
\hline No & $17(30.9 \%)$ & $14(25.5 \%)$ & & & \\
\hline Yes & $38(69.1 \%)$ & $41(74.5 \%)$ & & & \\
\hline
\end{tabular}

${ }^{1}$ Unadjusted. CRC - colorectal cancer, T2D - type 2 diabetes, GST - glutathione S-transferase. SNP* - GSTP1 polymorphism Ile 105Val, heterozygous (Ile/Val) or homozygous Val/Val genotype.

\section{Discussion}

This study attempts to better understand the role of GST gene polymorphism as a potential factor increasing the risk of CRC in T2D patients. As GST are involved in the processing of reactive oxygen, lipid peroxidation products and some key metabolites of toxicants, the potential links between genetic polymorphisms of these enzymes and the pathogenesis of T2D and CRC seem reasonable. Functional polymorphisms of GST genes have been reported to be involved in the pathogenesis of T2D $[16,17]$. One of the risk factors for diabetes is oxidative stress which is known to be implicated in insulin resistance, $\beta$-cell dysfunction and impaired glucose tolerance. Glutathione S-transferases among other functions act as scavengers for reactive oxygen species reducing the oxidative stress in cells. That is why the GST gene variants associated with a decline or lack of catalytic activity might increase the risk of T2D [17]. Moreover, it is known that GST gene polymorphisms are involved in the development of malignancies, such as gastric cancer [18], lung cancer [19] or colorectal cancer [7].

The presence or absence of GST gene polymorphisms and their combined effects have been suggested as a risk factor for T2D and CRC, but the association between GST gene polymorphism and the risk of CRC in T2D patients has not yet been investigated. Our results showed no relationship between studied polymorphisms and occurrence of CRC in T2D patients. There were also no statistically significant differences in the distribution of GST gene polymor- 
Table 5. GST gene polymorphism in T2D patients with CRC in comparison to the control group

\begin{tabular}{|c|c|c|c|c|c|}
\hline Variable & $\begin{array}{l}\text { T2D+, CRC+ } \\
(n=55)\end{array}$ & $\begin{array}{l}\text { T2D-, CRC- } \\
(n=55)\end{array}$ & $\mathrm{OR}^{1}$ & $95 \% \mathrm{Cl}$ & $P$-value \\
\hline \multicolumn{6}{|l|}{ GSTP1: } \\
\hline Ile/lle & $24(43.6 \%)$ & $26(47.3 \%)$ & & & \\
\hline Ile/Val & $28(50.9 \%)$ & $24(43.6 \%)$ & & & \\
\hline Val/Val & $3(5.5 \%)$ & $5(9.1 \%)$ & & & \\
\hline \multicolumn{6}{|l|}{ GSTP1: } \\
\hline Ile/lle or Ile/Val & $52(94.5 \%)$ & $50(90.9 \%)$ & Ref. level & & \\
\hline Val/Val & $3(5.5 \%)$ & $5(9.1 \%)$ & 0.58 & $0.13-2.54$ & 0.4673 \\
\hline \multicolumn{6}{|l|}{ GSTT1: } \\
\hline Wild type & $45(81.8 \%)$ & $46(83.6 \%)$ & Ref. level & & \\
\hline Null/null & $10(18.2 \%)$ & $9(16.4 \%)$ & 1.14 & $0.42-3.06$ & 0.8009 \\
\hline \multicolumn{6}{|l|}{ GSTM1: } \\
\hline Wild type & $27(49.1 \%)$ & $32(58.2 \%)$ & Ref. level & & \\
\hline Null/null & $28(50.9 \%)$ & $23(41.8 \%)$ & 1.44 & $0.68-3.06$ & 0.3398 \\
\hline \multicolumn{6}{|l|}{ Combined: } \\
\hline $\mathrm{P} 1=$ wild, $\mathrm{M} 1=$ wild, $\mathrm{T} 1=$ wild & $10(18.2 \%)$ & $14(25.5 \%)$ & & & \\
\hline $\mathrm{P} 1=$ wild, $M 1=$ wild, $\mathrm{T} 1=$ null $/$ null & $1(1.8 \%)$ & $3(5.5 \%)$ & & & \\
\hline P1 = wild, M1 = null/null, T1 = wild & $10(18.2 \%)$ & $8(14.5 \%)$ & & & \\
\hline P1 = wild, $M 1=$ null $/$ null, $T 1=$ null $/$ null & $3(5.5 \%)$ & $1(1.8 \%)$ & & & \\
\hline $\mathrm{P} 1=\mathrm{SNP} *, \mathrm{M} 1=$ wild, $\mathrm{T} 1=$ wild & $12(21.8 \%)$ & $13(23.6 \%)$ & & & \\
\hline $\mathrm{P} 1=\mathrm{SNP} *, \mathrm{M} 1=$ wild, $\mathrm{T} 1=$ null $/$ null & $4(7.3 \%)$ & $2(3.6 \%)$ & & & \\
\hline $\mathrm{P} 1=\mathrm{SNP}^{\star}, \mathrm{M} 1=$ null$/$ null, $\mathrm{T} 1=$ wild & $13(23.6 \%)$ & $11(20.0 \%)$ & & & \\
\hline $\mathrm{P} 1=\mathrm{SNP} \mathrm{P}^{*} \mathrm{M} 1=$ null $/$ null, $\mathrm{T} 1=$ null $/$ null & $2(3.6 \%)$ & $3(5.5 \%)$ & & & \\
\hline \multicolumn{6}{|l|}{ GST polymorphism presence: } \\
\hline No & $10(18.2 \%)$ & $14(25.5 \%)$ & & & \\
\hline Yes & $45(81.8 \%)$ & $41(74.5 \%)$ & & & \\
\hline
\end{tabular}

CRC - colorectal cancer, T2D - type 2 diabetes, GST - glutathione S-transferase. SNP* - GSTP1 polymorphism Ile 105Val, heterozygous (Ile/Val) or homozygous Val/Val genotype.

phisms between T2D, CRC and T2D/CRC patients and population without T2D and CRC.

Recently published meta-analysis indicates that the GSTM1 null genotype is associated with an increased CRC risk in Asians and Caucasians, the GSTT1 null and GSTM1/GSTT1 null genotypes were associated with an increased CRC risk in Asians [20]. Meta-analysis of 25 studies evaluating the role of GSTM1/GSTT1 null polymorphisms in determining the risk of T2D showed that GSTM1 and GSTT1 null genotypes increase the risk of T2D alone, in combination or with regards to ethnicity [21]. In fact, it may not be uncommon that the same polymorphism played different roles in CRC and T2D risk among different ethnic populations and may contribute to the inconsistency of results. Moreover, environmental factors, such as metformin-induced chemoprevention for CRC [22, 23], the CRC protective effect of thiazolidinediones in the treatment of diabetes [24] may have contributed to the lack of correlation between the GST gene polymorphism and the risk of developing $\mathrm{CRC}$ in the Polish population.

To date, little research investigated the genetic factors associated with the cancer risk in T2D patients. Sun et al. found that in T2D patients, rs1111875 but not the rs7923837 in HHEX gene was associated with the occurrence of CRC and indicated that the two variants of HEEX gene could be risk factors for CRC in the general population, independent of T2D [25]. De Kort et al. showed that the presence of unfavorable alleles in insulin-like growth factor gene increased the risk of CRC in T2D patients [26]. To the best of our 
knowledge, our study is the first to simultaneously consider T2D with GST gene polymorphisms in relation to CRC risk.

The limitation of the study is a relatively small number of patients in each group, which leads to the conclusion that it should be viewed as a pilot study. Nevertheless, the data obtained are possibly stimulating for further investigation in this area. Both T2D and CRC are complex chronic diseases and their development is affected by genetic as well as environmental factors. Therefore, extending the analysis to further genetic and environmental factors and taking into account their mutual interactions will be a further step in the search for the relationship between T2D and an increased risk of CRC.

\section{Acknowledgments}

Project financed under the program of the Minister of Science and Higher Education called "Regional Initiative of Excellence" in the years 2019-2022, project no. 024/RID/2018/19, amount of financing: PLN 11999000.00

Project supported by the following grant from the National Center of Science: "The polymorphism of GST genes and consumption of red meat in the risk of colorectal cancer" agreement No. UMO-2013/09/B/ NZ7/03910.

The Funders had no role in study design, data collection and analysis, preparation of the manuscript or decision to publish.

\section{Conflict of interest}

The authors declare no conflict of interest.

\section{References}

1. Gonzalez N, Prieto I, del Puerto-Nevado L, Portal-Nuñez S, Ardura JA, Corton M, Fernández-Fernández B, Aguilera O, Gomez-Guerrero C, Mas S, Moreno JA, Ruiz-Ortega M, Sanz AB, Sanchez-Niño MD, Rojo F, Vivanco F, Esbrit P, Ayuso C, Alvarez-Llamas G, Egido J,García-Foncillas J, Ortiz A, Diabetes Cancer Connect Consortium. 2017 update on the relationship between diabetes and colorectal cancer: epidemiology, potential molecular mechanisms and therapeutic implications. Oncotarget 2017; 8: 18456-18485.

2. Khodaeian M, Enayati S, Tabatabaei-Malazy O, Amoli MM Association between genetic variants and diabetes mellitus in Iranian populations: a systematic review of observational studies. J Diab Res 2015; 2015: 585917.

3. Piechowska AM, Wawszczak M, Cedro A, Głuszek S. Suppressor genes as molecular markers of colorectal cancer - a review of the latest reports. Medical Studies 2020; 36: $35-45$.

4. Thier R, Brüning T, Roos PH, Rihs HP, Golka K, Ko Y, Bolt HM. Markers of genetic susceptibility in human environmental hygiene and toxicology: the role of selected CYP, NAT and GST genes. Int J Hyg Environ Health 2003; 206: 149-171.
5. Hollman AL, Tchounwou PB, Huang HC. The Association between gene-environment interactions and diseases involving the human GST superfamily with SNP variants. Int J Environ Res Public Health 2016; 13: 379.

6. Sun L, Zhang Y, Xiong Y. GSTM1 and GSTT1 null genotype and diabetic retinopathy: a metaanalysis. Int J Clin Exp Med 2015; 8: 1677-1683.

7. Klusek J, Nasierowska-Guttmejer A, Kowalik A, Wawrzycka I, Lewitowicz P, Chrapek M, Głuszek S. GSTM1, GSTT1, and GSTP1 polymorphisms and colorectal cancer risk in Polish nonsmokers. Oncotarget 2018; 9: 21224-21230.

8. Grubisa I, Otasecvic P, Despotovic N, Dedic V, Milašin J, Vucinic N. Genetic polymorphism of glutathione S-transferase P1 (GSTP1) Ile105Val and susceptibility to atherogenesis in patients with type 2 diabetes mellitus. Genetika 2013; 45: 227-236.

9. Orlewski J, Orlewska E. Effects of genetic polymorphisms of glutathione S-transferase genes (GSTM1, GSTT1 and GSTP1) on the risk of diabetic nephropathy: a meta-analysis. Pol Arch Med Wew 2015; 125: 649-658.

10. Raza ST, Abbas S, Ahmad A, Ahmed F, Zaidi ZH, Mahdi F. Association of glutathione S-transferase (GSTM1 and GSTT1) and FTO gene polymorphisms with type 2 diabetes mellitus cases in northern India. BJMG 2014; 17: 47-54.

11. Rodrigues-Fleming GH, de Mendonca Fernandes GM, Russo A, Biselli-Chicote PM, Netinho JG, Pavarino EC, Goloni-Bertolo EM. Molecular evaluation of glutathione $\mathrm{S}$ transferase family genes in patients with sporadic colorectal cancer. World J Gastroenterol 2018; 24: 4462-4471.

12. Hayes JD, Pulford DJ. The glutathione S-transferase supergene family: regulation of GST and the contribution of the isoenzymes to cancer chemoprevention and drug resistance part I. Crit Rev Biochem Mol Biol 1995; 30: 445-600.

13. American Diabetes Association. Diagnosis and classification of diabetes mellitus. Diabetes Care 2010; 33 Suppl 1: S62-S69.

14. Venugopal A, Stoffel EM. Colorectal cancer in young adults. Curr Treat Options Gastroenterol 2019; 17: 89-98.

15. Selph S, Dana T, Blazina I, Bougatsos C, Patel H, Chou R. Screening for type 2 diabetes mellitus: a systematic review for the U.S. Preventive Services Task Force. Ann Intern Med 2015; 162: 765-776.

16. Banerjee $M$, Vats P. Reactive metabolites and antioxidant gene polymorphisms in type 2 diabetes mellitus. Indian J Hum Genet 2014; 20: 10-19.

17. Gusti AMT, Qusti SY, Bahijri SM, Toraih EA, Bokhari S, Attallah SM, Alzahrani A, Aslhehri WMA, Alotaibi H, Fawzy MS. Glutathione S-transferase (GSTT1 rs17856199) and nitric oxide synthase (NOS2 rs 2297518) genotype combination as potential oxidative stress-related molecular markers for type 2 diabetes mellitus. Diabetes Metab Syndr Obes 2021; 14: 1385-1403.

18. Chen B, Cao L, Zhou Y, Yang P, Wan HW, Jia GQ, Liu L, Wu XT. Glutathione S-transferase T1 (GSTT1) gene polymorphism and gastric cancer susceptibility: a metaanalysis of epidemiologic studies. Dig Dis Sci 2010; 55: 1831-1838.

19. Kant Shukla R, Kant S, Mittal B, Bhattacharya S. Comparative study of GST polymorphism in relation to age in COPD and lung cancer. Tuberk Toraks 2013; 61: 275-282.

20. Song L, Yang C, He XF. Individual and combined effects of GSTM1 and GSTT1 polymorphisms on colorectal can- 
cer risk: an updated meta-analysis. Biosci Rep 2020; 40: BSR20201927.

21. Nath S, Das S, Bhowmik A, Ghosh SK, Choudhury Y. The GSTM1 and GSTT1 null genotypes increase the risk for type 2 diabetes mellitus and the subsequent development of diabetic complications: a meta-analysis. Curr Diabetes Rev 2019; 15: 31-43.

22. Higurashi T, Nakajima A. Metformin and colorectal cancer. Front Endocrinol 2018; 9: 622.

23. Liu F, Yan L, Wang Z, Lu Y, Chu Y, Li X, Liu Y, Rui D, Nie S, Xiang $\mathrm{H}$. Metformin therapy and risk of colorectal adenomas and colorectal cancer in type 2 diabetes mellitus patients: a systematic review and meta-analysis. Oncotarget 2017; 8: 16017-16026.

24. Liu Y, Jin PP, Sun XC, Hu TT. Thiazolidinediones and risk of colorectal cancer in patients with diabetes mellitus: a meta-analysis. Saudi J Gastroenterol 2018; 24: 75-81.

25. Sun R, Liu JP, Gao C, Xiong YY, Li M, Wang YP, Su YW, Lin M, Jiang AL, Xiong LF, Xie Y, Feng JP. Two variants on T2DM suspectible gene HHEX are associated with CRC risk in a Chinese population. Oncotarget 2015; 7: 2977029779.

26. De Kort S, Simons CCJM, van den Brandt PA, JanssenHeijnen MLG, Sanduleanu S, Masclee AAM, Weijenberg MP. Diabetes mellitus, genetic variants in the insulin-like growth factor pathway and colorectal cancer risk. Int J Cancer 2019, 145: 1774-1781.

\section{Address for correspondence:}

\section{Justyna E. Klusek}

Collegium Medicum

Jan Kochanowski University

ul. Żeromskiego 5, 25-369 Kielce, Poland

E-mail: justynaklusek@tlen.pl 